https://doi.org/10.32689/2618-0065-2020-3(5)-110-119

Кравцов Максим Олександрович, аспірант, ПрАТ «Вищий Навчальний Заклад «Міжрегіональна Академія Управління Персоналом», , 03039, м. Київ, вул. Фрометівська, 2, тел.: (044) 264-52-54, e-mail: mishako2707@gmail.com, https://orcid.org/0000-0002-8615-6983

\title{
ОРГАНІЗАЦІЙНО-ПРАВОВІ МЕХАНІЗМИ ФУНКЦІОНУВАННЯ ТЕЛЕФОННИХ «ГАРЯЧИХ ЛІНІЙ» ОРГАНІВ ВИКОНАВЧОЇ ВЛАДИ
}

Анотація. У статті проаналізовано сучасний стан організаційноправових механізмів функціонування телефонних «гарячих ліній» органів виконавчої влади в Україні. Акцентовано увагу на основних проблемних аспектах здійснення державної політики у досліджуваній сфері. Розглянуто основний принцип роботи «гарячих ліній» на прикладі урядової телефонної «гарячої лінії». Розкрито питання необхідності усунення існуючих прогалин у законодавчій базі та їі удосконалення.

Доведено, що законодавча норма щодо визначення однакового терміну розгляду для всіх видів звернень певним чином унеможливлює повноцінне забезпечення реалізації права на усне звернення.

У дослідженні типової структури Порядку роботи будь-якої «гарячої лінії» визначили перелік основних вимог, що повинні фіксуватись у кожному розділі.

Проаналізовано діяльність державної установи «Урядовий контактний центр», що забезпечує роботу урядової «гарячої лінії», фахівці якої приймають звернення до всіх центральних органів виконавчої влади.

Акцентували увагу на Порядку взаємодії органів виконавчої влади, Секретаріату Кабінету Міністрів України та державної установи «Урядовий контактний центр», відповідно до якого здійснюється комунікація між громадянами та представниками владних структур. Не оминули увагою і Концепцію створення Національної системи опрацювання звернень громадян, реалізація якої була запланована на 2013 рік, проте на сьогодні її положення знаходиться на різних етапах виконання, а деякі пункти виконано не в повному обсязі.

Проте, незважаючи на зазначені недоліки, можна 3 упевненістю говорити про урядову «гарячу лінію» як найуспішніший соціальний проект в частині взаємовідносин між громадянами та органами виконавчої влади. Саме завдяки даній «гарячій лінії» мільйони громадян і не лише з України мають змогу у цілодобовому режимі звернутись до представників влади та висловити своє невдоволення, прохання, скаргу, пропозицію, а не рідко і подяку. 
Взагаліосновна проблема полягає у недосконалості та суттєвих прогалинах існуючого законодавства у досліджуваній на ми сфері.

Ключові слова: «гаряча лінія», звернення, комунікація, орган виконавчої влади, законодавство, порядок роботи, концепція.

Kravtsov Maxim Oleksandrovich, graduate student , Interregional Academy of Personnel Management, 03039, Kyiv, str. Frometivska, 2, tel.: (044) 264-52-54, e-mail: mishako2707@gmail.com, https://orcid.org/0000-0002-8615-6983

\section{ORGANIZATIONAL AND LEGAL MECHANISMS OF THE FUNCTIONING OF TELEPHONE "HOT LINES" OF AUTHORITIES OF EXECUTIVE AUTHORITIES}

Abstract. The article analyzes the current state of organizational and legal mechanisms of functioning of telephone "hotlines" of executive authorities in Ukraine. Attention is focused on the main problematic aspects of the implementation of public policy in the research area. The basic principle of operation of "hot lines" on the example of a government telephone hotline is considered. The question of necessity of elimination of existing gaps in the legislative base and its improvement is solved.

They came to the conclusion that the legislative provision on the definition of a single review period for all types of appeals in some way makes it impossible to fully enforce the right to an oral appeal.

In a study of the typical structure of the Order of Operation of any "hotline" identified a list of basic requirements that should be recorded in each section.

The activity of the state agency "Government Contact Center", which provides the work of the government "hot line", whose specialists accept appeals to all central executive bodies, is analyzed.

They emphasized on the Order of interaction between the executive authorities, the Cabinet of Ministers of Ukraine Secretariat and the Governmental Contact Center, according to which communication between citizens and representatives of governmental structures is carried out. The concept of creation of the National system of processing of appeals of citizens, implementation of which was planned for 2013, is not overlooked, but today its provision is at different stages of implementation, and some items have not been fully implemented.

However, despite these shortcomings, one can confidently refer to the government's hotline as the most successful social project in terms of relations between citizens and executive authorities. It is thanks to this hotline that millions of citizens, and not only from Ukraine, are able to contact the authorities on a 24hour basis and express their dissatisfaction, request, complaint, proposal, and not rarely gratitude.

In general, let us come to the conclusion that the main problem is the imperfection and significant gaps in the existing legislation in our field of study. 
Key words: hotline, appeals, communication, executive authority, legislation, work order, concept.

Постановка проблеми. Сьогодні організація функціонування телефонних «гарячих ліній» органів державної влади вважається універсальним та найважливішим засобом комунікації між ними та громадянами. Ефективність функціонування «гарячої лінії» будь-якого органу державної влади забезпечується за рахунок обробки максимальної кількості звернень, протягом чітко визначеного терміну, а також за рахунок вчасного виявлення та усунення правопорушень з боку посадових осіб органів державної влади.

Діяльність «гарячих ліній» пов'язана безпосередньо з наданням кожній людині права звернутися, яке закріплено Конституцією України. Так, відповідно до ст. 40 Основного закону держави, кожен громадянин наділений правом направлення письмового звернення або звернення в усній формі до будь-якого органу державної влади або місцевого самоврядування, а також до їх посадових осіб, які, у свою чергу, зобов'язані ці звернення розглядати та надавати кваліфіковану відповідь у встановлений законодавством термін.

Незважаючи на те, що об'єктом нашого дослідження стала «гаряча лінія» саме органів виконавчої влади як однієї зі складових органів державної влади, організаційно-правові механізми функціонування подібних ліній можна розглянути як загальний спосіб забезпечення конституційного права на звернення.

Аналіз останніх досліджень і публікацій. Дослідженню «гарячих ліній» та безпосередньо поданих за їх допомогою звернень громадян присвячено широке коло наукових праць вітчизняних та іноземних вчених. Важливість окресленої проблематики зумовлена тим, що вона стала предметом наукового інтересу як юристів, так і фахівців інших галузей, зокрема представників науки державного управління. Маються на увазі праці Г. Котляревської, Отто Люхтергандта, В. Тимощука, О.Чуб, О. Бабінової, Л. Загайнової, В. Сорока, Н. Дніпренко В. Авер'янова, О. Бандурки, В. Колпакова,С. Стеценка, О. Кузьменко, а також Ю. Лагутова, В. Соболя, В. Новікова та інших.

На цей час ще не до кінця дослідженими $є$ проблеми забезпечення реалізації права громадян на звернення до органів влади в Україні саме шляхом подання їх за допомогою «гарячих ліній». А отже, бракує системних, цілісних наукових праць, у яких би обгрунтовувалися питання модернізації «гарячих ліній» у нашій державі.

Мета статті. На основі аналізу законодавчої бази та наукових досліджень проаналізувати сучасний стан організаційно-правового механізму функціонування телефонних «гарячих ліній» органів виконавчої влади в Україні та пріоритетні орієнтири їх розвитку.

Виклад основного матеріалу. Варто зауважити, що взагалі право на звернення можуть реалізувати не тільки громадяни України, але і будь-хто 3 громадян інших країн, які законно перебувають на нашій території [1]. Це 
право закріплено не лише в ст. 40 Конституції України [2], але і в інших нормативних документах, що стосуються забезпечення прав та свобод людини і громадянина.

Одразу зазначимо, що наше дослідження зосереджувалось на прикладі роботи урядової телефонної «гарячої лінії», яка співпрацює 3 органами виконавчої влади та Секретаріатом Кабінету Міністрів України, а не ліній всіх органів влади.

Нами проаналізовано діяльність «гарячої лінії» як елемент реалізації права на звернення. Тому основними документами, на які ми опираємося, $є$ Закон України «Про звернення громадян» [3] та Указ Президента України «Про першочергові заходи щодо забезпечення реалізації та гарантування конституційного права на звернення до органів державної влади та органів місцевого самоврядування».

У ст. 19 Закону «Про звернення громадян» закріплено перелік обов’язків органів державної влади стосовно розгляду звернень громадян, а відповідно до указу Президента України «Про першочергові заходи щодо забезпечення реалізації та гарантування конституційного права на звернення до органів державної влади та органів місцевого самоврядування» Кабінет Міністрів України, міністерства, інші ЦОВВ, міські та районні державні адміністрації, а також органи місцевого самоврядування повинні забезпечити належну роботу зі зверненнями, створивши «гарячі лінії» та «телефони довіри».

Якщо говорити про організаційно-правове забезпечення діяльності «гарячих ліній» в цілому, то варто зауважити, що кожна телефонна «гаряча лінія» повинна працювати відповідно до затвердженого порядку, типова структура якого виглядає таким чином.

У розділі «Загальні положення» зазначаються основні нормативноправові акти, відповідно до яких лінія здійснює свою діяльність; організація роботи, механізми прийому, реєстрації, розгляду та надання відповіді на звернення; перелік документів, якими у своїй діяльності керуються посадові особи, уповноважені на забезпечення роботи лінії.

У розділі «Порядок роботи телефонної лінії» зазвичай розміщують адресу, графік роботи та номер телефону лінії; який структурний підрозділ відповідальний за їі роботу; якими документами закріплюються функції осіб, що відповідають за роботу такої лінії.

Основні завдання роботи «гарячої лінії» відображені у третьому розділі типового порядку«Основні завдання роботи «гарячої лінії».

Що стосується наступного розділу «Порядок прийому, реєстрації та розгляду звернень», то в ньому загалом визначаються випадки, в яких надається консультація або реєструється звернення; що робити, якщо громадянин звернувся не за компетенцією; як вчинити, якщо факти, які навів заявник, потрібно додатково вивчити; перелік даних, які заявник повинен зазначити звертаючись на «гарячу лінію»; порядок дій у випадку надходження анонімного звернення; яким чином ведеться діловодство за зверненнями та здійснюється контроль за їх розглядом.

У п’ятому розділі фіксують «Терміни розгляду звернень». 
I, в останньому розділі «Правила ведення телефонної розмови» прописують чіткий алгоритм ведення розмови; не пізніше якого дзвінка фахівець повинен підняти слухавку; з чого починається розмова; мова, якою вона ведеться; необхідність уточнення інформації, наданої заявником; інформування заявника щодо реєстрації звернення чи орієнтовного терміну його розгляду, а також, обов'язково, яким чином повинна бути завершена розмова.

Говорячи про об'єкт нашого дослідження, а саме урядову «гарячу лінію», варто зазначити, що поштовхом до іiі створення стало саме формування системного підходу до забезпечення оперативності реагування на звернення з боку виконавчих органів, а також їх взаємодії між собою під час їх розгляду.

Державну установу «Урядовий контактний центр», яка забезпечує роботу урядової «гарячої лінії», було створено у травні 2009 року. На сьогодні до неї надходять звернення, які стосуються діяльності всіх без виключення органів виконавчої влади.

Зупинимось більш детально саме на Порядку взаємодії органів виконавчої влади, Секретаріату Кабінету Міністрів України та державної установи «Урядовий контактний центр» [5]. Відповідно до нього, Урядовий контактний центр разом 3 виконавчими органами повинні забезпечити належний та вчасний розгляд звернень, що реєструються заявниками на урядовій «гарячій лінії», вживати заходи для вирішення порушуваних у них питаннях, а також здійснювати моніторинг їх розгляду.

Для забезпечення цих цілей в Урядовому контактному центрі створена та діє електронна база даних звернень, до якої мають доступ органи виконавчої влади, відповідно до наданих їм кодів доступу. Для фіксування кожного звернення необхідно завести реєстраційну картку [6]. Це робиться під час телефонної розмови із заявником, в якій повинна міститись наступна інформація:

особисті дані заявників; для юридичних осіб - назва підприємства, код ЄДРПОУ тощо;

суть питання, з яким він звернувся.

Після збереження даної інформації зареєстрованому зверненню автоматично присвоюється реєстраційний номер.

Трапляються випадки, коли громадяни не бажають називати своїх даних (зазвичай вони стосуються невиплати заробітної плати, оскільки бояться подальшого звільнення у разі інформування про звернення роботодавця), тоді звернення можна реєструвати як анонімне та в установленому порядку надсилати його на розгляд компетентному виконавчому органу, який вже на власний розсуд вирішує долю його розгляду (така норма визначена в Законі України «Про звернення громадян»). Зареєстроване звернення у той же день направляється на розгляд компетентному органу (в електронній формі), в якому повинна бути визначена відповідальна за розгляд звернень особа (визначається на рівні керівника). 
Про прийняття або перенаправлення звернення, відповідальна особа ставить відмітку в електронній базі даних. На цьому етапі моніторингу нас зацікавило питання, що робити у випадку не внесення інформації про прийняття, оскільки останнім часом простежується помітна недбалість та бездіяльність з боку представників органів виконавчої влади. Виявилось, що контролювати такі ситуації повинні відповідальні особи Урядового контактного центру. Тобто, у випадку не внесення відмітки з боку органу виконавчої влади, Урядовий контактний центр повинен з'ясувати причину та вжити відповідних заходів для забезпечення виконання даної норми. Якщо ж звернення було надіслано не за компетенцією, то орган, до якого воно надійшло, не пізніше ніж на наступний день повинен переадресувати його до іншого органу, який уповноважений на вирішення такого роду питань.

Відповідно до згаданого Порядку органи виконавчої влади повинні забезпечувати розгляд вчасно та об'єктивно, перевіряти факти, що викладені у зверненнях, а також вживати заходів для отримання додаткової інформації, у разі недостатності іiї у змісті звернення.

Що стосується результатів розгляду звернень, то про них виконавчі органи влади інформують заявників в установленому законодавством порядку, а до бази даних вносять інформацію разом з електронною копією листа.

Досліджуючи питання термінів розгляду звернень, нами було з'ясовано, що відповідно до Закону України «Про звернення громадян» на розгляд звернення визначено місячний термін, а у випадку необхідності додатково опрацювання не більше 45 днів, але з обов'язковим інформуванням про це. Варто зауважити, що терміни визначені однакові для всіх видів звернень. Проте дана норма певним чином унеможливлює повноцінне забезпечення реалізації права на усне звернення. Чому? Річ у тім, що таке звернення дійсно може бути «гарячим» (потребувати негайного розгляду), а для того, щоб скоротити термін його розгляду, відповідно до ст. 20 зазначеного закону, необхідно надати виключно письмове обгрунтування такого прохання. Очевидним $\epsilon$ те, що під час викладення звернення в усній формі забезпечення даної формальності неможливе.

Важливим аспектом діяльності урядової «гарячої лінії» $\epsilon$ аналіз результатів розгляду звернень та щотижневе інформування Кабінету Міністрів України про це. В структурі даної державної установи є управління організаційно-аналітичної роботи, що проводить аналіз звернень та на його основі повідомляє про найактуальніші питання, що потребують вирішення 3 боку органів виконавчої влади.

Також важливим чинником в роботі згаданої «гарячої лінії» вважається співпраця з ОВВ, що дає змогу визначення чіткого механізму оперативного реагування на звернення, що стосуються надзвичайних ситуацій.

Таким чином, можна зробити висновок, що у Порядку взаємодії такої «гарячої лінії» 3 органами виконавчої влади передбачено достатньо зрозумілий механізм співпраці. 
Не можливо залишити поза увагою Концепцію створення Національної системи опрацювання звернень до органів виконавчої влади [7]. Відповідно до зазначеного документа Національна система опрацювання звернень до органів виконавчої влади повинна удосконалювати роботу зі зверненнями. Концепцією створення Національної системи опрацювання звернень до органів виконавчої влади передбачено створити регіональні контактні центри на рівні областей та забезпечити їх взаємодію з Урядовим контактним центром. Окрім того, центральні органи виконавчої влади також отримали доручення удосконалити роботу своїх телефонних «гарячих ліній». Нагадаємо, що подібні «гарячі лінії» на шляху свого створення мають на меті спростити умови подання звернень та підвищити їх оперативний розгляд.

У ході дослідженнязясовано, що сьогодні, кожна частина основних положень зазначеної Концепції знаходиться на різних етапах виконання, деякі пункти виконано не в повному обсязі. На момент проведення дослідження вже створено та функціонує 17 центрів в місті Київ, Дніпропетровській, Закарпатській, Запорізькій, Івано-Франківській, Кіровоградській, Київській, Луганській, Львівській, Миколаївській, Одеській, Полтавській, Рівненській, Сумській, Херсонській, Хмельницькій та Черкаській областях. Нажаль, робота щодо їх створенню значно відстає від встановлених термінів. Крім того, деякі норми взагалі не виконано. Так, наприклад, не введено в дію принцип «єдиного вікна», відповідно до якого повинні забезпечуватись єдині стандарти роботи зазначених ліній, служб та центрів.

Але, попри визначені недоліки, нами було відслідковано і позитивні аспекти в діяльності урядової «гарячої лінії» як ключового суб'єкта Національної системи опрацювання звернень до органів виконавчої влади.

Так можна сказати, що урядова «гаряча лінія» $\epsilon$ найуспішнішим соціальним проектом в частині взаємовідносин між громадянами та органами виконавчої влади [8]. IIÏ досвід роботи можна вважати унікальним. Перш за все тому, що сьогодні, в Україні, немає іншого комунікативного центру, який би у цілодобовому режимі надавав людям допомогу у розв'язанні життєвих проблем. По-друге, звертатися можна як з будь-якого регіону України безкоштовно, так і з-за кордону.

3 моменту створення лінії вже зареєстровано понад 8 мільйонів звернень.

Робота лінії постійно удосконалюється. У 2012 році запрацював офіційний веб-сайт Урядового контактного центру www.ukc.gov.ua [9], за допомогою якого 3'явилась можливість прийому та надіслання звернень в електронному вигляді. А у 2018 році даний сайт було модернізовано до сучасних стандартів. Це, в свою чергу, наблизило України до певних світових стандартів.

У листопаді 2016 року відбулось запровадження багатоканального скороченого номера урядової «гарячої лінії» 1545. Дзвінки на даний номер $є$ безкоштовними як зі стаціонарних телефонів, так і з телефонів мобільних операторів, які діють на території України. 
Не можливо залишити осторонь і питання консультування громадян. Фахівці лінії консультують щодо суспільно-гострих питань (отримання субсидії, пенсійного забезпечення, переміщення 3 окупованих територій тощо).

Висновки та перспективи подальших досліджень. Підсумовуючи наведене, можна зробити висновок, що в організаційно-правовому забезпеченні роботи діяльності «гарячих ліній» $\epsilon$ багато прогалин, які потрібно заповнити в першу чергу шляхом внесення змін до чинного законодавства України, оскільки функціонування «гарячих ліній» та подання звернень за їх допомогою є своєрідною формою участі громадян у соціальноекономічних, політичних процесах, які в свою чергу є складовою публічної влади. «Гарячі лінії» забезпечують взаємодію суспільства й держави, а також сприяють ефективному вирішенню проблем, які виникають в процесі реалізації прав та законних інтересів. Позитивний рівень ефективності функціонування даного механізму впливає на становлення правової держави, а також свідчить про демократизм у всіх сферах суспільного життя.

Ми дійшли висновку, що в першу чергу необхідно усунути недоліки правового регулювання, вирішення яких запобігатиме подальшому порушенню прав і законних інтересів громадян. Зокрема:

1) існує необхідність посилити відповідальність посадових осіб за порушення законодавства у сфері забезпечення конституційного права громадян на звернення, передбачивши встановлення чітких та суворих санкцій за перешкоджання здійсненню права громадян на звернення до органів влади й роботі таких органів 3 розгляду звернень громадян, переслідування громадян у зв'язку з їхніми зверненнями до органів влади й до відповідних посадових осіб, незаконне використання або поширення відомостей про приватне життя громадян, що стали відомими у зв'язку зі зверненнями останніх у владні структури;

2) необхідно добиватися прозорості всієї системи роботи зі зверненнями 3 використанням сучасних інформаційних технологій;

3) надати доручення органам державної влади та місцевого самоврядування щодо поліпшення роботи зі зверненнями громадян, поданими у формі пропозицій, які $\epsilon$ механізмом безпосередньої участі громадян у державному управлінні, у вирішенні загальносуспільних справ та питань місцевого значення, можливість активного впливу громадянина на розробку та здійснення державної політики.

\section{Jimepamypa:}

1. Новіков В.Д., Мицак Б.Н. До питання захисту прав та законних інтересів громадян.Наукові записки Львівського університету бізнесу та права: зб. наук. пр. / Львів. ун-т бізнесу та права. Львів, 2011. URL: http://irbis-nbuv.gov.ua/ Nzlubp_2011_6_37.pdf (дата звернення: 20.05.2020).

2. Конституція України. Відомості Верховної Ради України. 1996. № 30.141 с.

3. Про звернення громадян: Закон України «» від 02.10.1996 № 393/96-ВР. Відомості Верховної Ради України. 1996. № 47. С. 256. 
4. Про першочергові заходи щодо забезпечення реалізації та гарантування конституційного права на звернення до органів державної влади та органів місцевого самоврядування: указ Президента України від 07.02.2008 № 109/2008. // База даних Верховної ради України / BP. URL: https://zakon.rada.gov.ua/laws/show/109/2008\#Text (дата звернення: 20.05.2020).

5. Про взаємодію органів виконавчої влади, Секретаріату Кабінету Міністрів України та державної установи "Урядовий контактний центр": постанова Кабінету Міністрів України «» від 12.08.2009 № 898URL: https://zakon.rada.gov.ua/laws/show/8982009-\%D0\%BF (дата звернення: 20.05.2020).

6. Про затвердження Класифікатора звернень громадян: постанова Кабінету Міністрів України від 24 вересня 2008 р. № 858. // База даних «Законодавство України». / BP України. URL: https://zakon.rada.gov.ua/laws/show/858-2008-\%D0\%BF/. (дата звернення: 20.05.2020).

7. Про схвалення Концепції створення Національної системи опрацювання звернень до органів виконавчої влади: розпорядження Кабінету Міністрів України «» від 09.06.2011 № 589-p. // База даних «Законодавство України». / BP України. URL: https://zakon.rada.gov.ua/laws/show/589-2011-\%D1\%80 (дата звернення: 20.05.2020).

8. Лагутов Ю.Е. Звернення громадян як важлива складова захисту прав і свобод людини та громадянина в Україні: аналітична записка / Національний інститут стратегічних досліджень. Київ, 2009. URL: http://old.niss.gov.ua/monitor/february2009/4.htm (дата звернення: 20.05.2020).

9. Офіційний веб-сайт державної установи «Урядовий контактний центр». URL: https://www.ukc.gov.ua/ (дата звернення: 20.05.2020). 


\section{References:}

1. Novikov, V. V., Mytsak, B. N. (2011). Do pitannya zahistu prav ta zakonnih interesiv gromadyan [The question of protection of rights and legitimate interests of citizens]. Naukovi zapysky Lvivskoho universytetu biznesu ta prava - Scientific notes of LUBP, 6, 159-163 [in Ukrainian].

2. Konstytutsiia Ukrainy [The Constitution of Ukraine]. (1996). Vidomosti Verkhovnoi Rady Ukrainy - Bulletin of Verkhovna Rada of Ukraine, 30. Art. 141 [in Ukrainian].

3. Zakon Ukrainy «Pro zvernennia hromadian» : vid 02.10.1996, № 393/96-VR [Law of Ukraine "On appeals of citizens" from 02.10.1996, № 393/96-VR]. Vidomosti Verkhovnoi Rady Ukrainy - Bulletin of Verkhovna Rada of Ukraine, 47. Art. 256 [in Ukrainian].

4. Ukaz Prezydenta Ukrainy «Pro pershocherhovi zakhody shchodo zabezpechennia realizatsii ta harantuvannia konstytutsiinoho prava na zvernennia do orhaniv derzhavnoi vlady ta orhaniv mistsevoho samovriaduvannia» : vid 07.02.2008, № 109/2008 [The Decree of the President of Ukraine "On priority measures to ensure the implementation and guarantee of the constitutional right to apply to state and local self-government bodies" from 07.02.2008, № 109/2008]. (2008). zakon.rada.gov.ua. Retrieved from https://zakon.rada.gov.ua/laws/show/109/2008\#Text [in Ukrainian].

5. Postanova Kabinetu Ministriv Ukrainy «Pro vzaiemodiiu orhaniv vykonavchoi vlady, Sekretariatu Kabinetu Ministriv Ukrainy ta derzhavnoi ustanovy "Uriadovyi kontaktnyi tsentr"» : vid 12.08.2009, № 898 [Resolution of the Cabinet of Ministers of Ukraine "On interaction between the executive authorities, the Secretariat of the Cabinet of Ministers of Ukraine and the Governmental Contact Center” from 12.08.2009, № 898]. (2009). zakon.rada.gov.ua. Retrieved from https://zakon.rada.gov.ua/laws/show/898-2009-\%D0\%BF [in Ukrainian].

6. Postanova Kabinetu Ministriv Ukrainy «Pro zatverdzhennia Klasyfikatora zvernen hromadian» : vid 24 veresnia 2008 r., № 858 Resolution of the Cabinet of Ministers of Ukraine “On approval of the Classifier of appeals of citizens"from 24.09.2008, № 858]. (2009). zakon.rada.gov.ua. Retrieved from https://zakon.rada.gov.ua/laws/show/858-2008-\%D0\%BF/ [in Ukrainian].

7. Rozporiadzhennia Kabinetu Ministriv Ukrainy «Pro skhvalennia Kontseptsii stvorennia Natsionalnoi systemy opratsiuvannia zvernen do orhaniv vykonavchoi vlady» : vid 09.06.2011, № 589-r [Resolution of the Cabinet of Ministers of Ukraine "On approval of the Concept of creation of the National system of processing of appeals to bodies of executive power" from 09.06.2011, № 589-r]. (2011). zakon.rada.gov.ua. Retrieved from https://zakon.rada.gov.ua/laws/show/589-2011-\%D1\%80 [in Ukrainian].

8. Lagutov, Yu. E. (2009). Zvernennya gromadyan yak vazhliva skladova zahistu prav $i$ svobod lyudini ta gromadyanina $v$ Ukrayini [The appeal of citizens as an important component of protection of human and citizen's rights and freedoms in Ukraine]. Kyiv. Retrieved from http://old.niss.gov.ua/monitor/february2009/4.htm [in Ukrainian].

9. Ofitsiinyi veb-sait derzhavnoi ustanovy «Uriadovyi kontaktnyi tsentr» [Official website of the governmental institution "Government Contact Center"]. www.ukc.gov.ua. Retrieved from https://www.ukc.gov.ua/ [in Ukrainian]. 